\title{
IMPLEMENTASI METODE BINET SIMON DAN METODE FUZZY LOGIC PADA APLIKASI TES KEMAMPUAN IQ (INTELLIGENCE QUOTIENT) DAN TIPE KECERDASAN (MULTIPLE INTELLIGENCE) UNTUK ANAK TUNARUNGU BERBASIS ANDROID
}

(Studi Kasus : SLB C YPALB Perwari Ancaran Kuningan)

\author{
Rio Andriyat K.,M.Kom \\ Studi Teknik Informatika \\ Fakultas Ilmu Komputer, Universitas Kuningan \\ rioandriyat@uniku.ac.id ${ }^{1}$,yogi.sanhari@hotmail.com ${ }^{2}$
}

\begin{abstract}
The first intelligence known by man is intelligence or intellectual acumen. Intelligence is mind intelligence, the intelligence function of thought can be used to solve a problem or situation quickly and precisely. Until now, many parents think that intelligence relates to calculations or any form of subjects that are difficult and challenging. However, in fact people have many forms of intelligence called intelligence type or multiple intelligences. This intelligence can be detected through psychological examination with measuring tools given in the form of the problems created by the psychologists to distinguish the person's behavior with others, improving self understanding, self evaluation, and self-acceptance. Intelligence is defined by IQ (Intelligence Quotient) which is grouped based on a comparison between the level of mental abilities (mental age) with age (chronological age). Based on test results, the android based application of IQ and multiple intelligence using Binet Simon method and Fuzzy Logic method for deaf children at SLB C YPALB Perwari Ancaran Kuningan can be done quickly, accurately, and the child's attention so that tests of IQ and multiple intelligence can be done more effective so that it can improve cognitive abilities and emotional, as well as the ability of intelligence of students, especially children with hearing impairment.
\end{abstract}

Keywords :IQ test, multiple intelligence, deaf children, binet simon method, fuzzy logic method, based android.

\section{PENDAHULUAN}

\subsection{Latar Belakang Masalah}

Bentuk kecerdasan pertama yang dikenal oleh manusia adalah kecerdasan intelegensi atau intelektual, kecerdasan didefinisikan berdasarkan $I Q$. Pengelompokan $I Q$ dilakukan berdasarkan perbandingan antara tingkat kemampuan mental (mental age) dengan tingkat usia (chronological age). Sebagaimana tes $I Q$ sering dianggap sebagai kendala oleh mereka yang sedang mencari pengetahuan tentang $I Q$ atau dalam pembelajarannya. Pasalnya, banyak yang menganggap tes $I Q$ sebagai 
hambatan yang bisa menjatuhkan mereka saat mengikuti proses. Pendapat itu tentu saja keliru, karena $I Q$ merupakan suatu pemeriksaan psikologi dengan alat-alat ukur tertentu dalam bentuk soal-soal tes yang diciptakan oleh para pakar psikologi untuk membedakan prilaku seseorang dengan orang lain.

Selama ini tes $I Q$ dan tipe kecerdasan pada anak berkebutuhan khusus tunarungu, kebanyakan masih menggunakan cara formal atau manual yaitu dilakukan dengan beberapa lembar kertas, menjawab pertanyaan dan menunggu hasilnya beberapa hari kemudian sehingga membutuhkan waktu yang cukup lama untuk mendapatkan hasil dari tes $I Q$ dan tipe kecerdasan. Akan tetapi akan sangat menarik jika sebuah tes $I Q$ dan dan tipe kecerdasan dilakukan menggunakan sebuah aplikasi yang memiliki tampilan-tampilan animasi serta dipadukan dengan permainan, penggunaan sarana teknologi yang canggih, dan penggunaan sistem misalnya android yang open platform, pengguna tidak hanya bermain namun juga mengetahui nilai $I Q$ dan tipe kecerdasannya dengan cepat dan tepat karena menggunakan metode Binet Simon dan metode Fuzzy Logic sehingga lebih efektif dan efisien dalam menentukan hasilnya.

Berdasarkan uraian tersebut, maka penulis mengambil judul "Implementasi Metode Binet Simon dan Metode Fuzzy Logic pada Aplikasi Tes Kemampuan IQ (Intelligence Quotient) dan Tipe Kecerdasan (Multiple Intelligence) untuk Anak Tunarungu Berbasis Android".

\subsection{Rumusan Masalah}

Berdasarkan permasalahan yang ada, penulis merumuskan masalah dalam penelitian ini sebagai berikut :

1. Bagaimana melakukan tes kemampuan IQ dan tipe kecerdasan pada anak tunarungu ?

2. Bagaimana mengimplementasikan metode Binet Simon dalam menentukan $I Q$ dan metode Fuzzy Logic dalam menentukan tipe kecerdasan pada anak tunarungu ?

3. Bagaimana merancang dan membangun aplikasi tes kemampuan $I Q$ dan tipe kecerdasan untuk anak tunarungu menggunakan metode Binet Simon dan metode Fuzzy Logic berbasis android?

\subsection{Batasan Masalah}

Adapun batasan masalah dalam penelitian ini adalah sebagai berikut :

1. Aplikasi ini digunakan untuk anak tunarungu jenjang SMALB (Sekolah Menengah Atas Luar Biasa).

2. Aplikasi ini menggunakan 90 soal yang terdiri dari soal matematika, logika dan bahasa isyarat, pada saat pelaksaan tes menggunakan 60 soal, dalam waktu 60 menit.

3. Aplikasi ini menggunakan metode Binet Simon untuk menentukan $I Q$ anak tunarungu dengan kriteria soal general comprehension, visual motor ability, aritmathic reasoning, memory and concentration, vocabulary dan verbal fluency, judgement and reasoning, dan metode Fuzzy Logic untuk menentukan tipe kecerdasan anak tunarungu dengan kriteria verballinguistik, logika-matematika, visual-spasial, intrapersonal, interpersonal, naturalis. 
4. Bahasa pemrograman yang digunakan dalam apikasi ini yaitu java yang dikompilasi menjadi sistem android (.apk) dan untuk database menggunakan SQLite Database.

5. Tools yang digunakan untuk membangun aplikasi ini yaitu Android Studio dengan minimal versi API 16.

\subsection{Tujuan dan Manfaat Penelitian \\ 1.4.1 Tujuan Penelitian}

Adapun tujuan dari penelitian ini adalah sebagai berikut :

1. Mengetahui tingkat kecerdasan dan kemampuan $I Q$ dan tipe kecerdasan anak tunarungu.

2. Mengimplementasikan metode Binet Simon dan metode Fuzzy Logic dalam tes kemampuan $I Q$ dan tipe kecerdasan untuk anak tunarungu.

3. Merancang dan membangun aplikasi tes kemampuan $I Q$ dan tipe kecerdasan untuk anak tunarungu menggunakan metode Binet Simon dan metode Fuzzy Logic berbasis android.

\subsubsection{Manfaat Penelitian}

Diharapkan penelitian ini dapat memberikan manfaat, yaitu :

1. Bagi Lembaga, untuk membantu dalam upaya pengembangan kemampuan kognitif dan emosional dari tes kemampuan $I Q$ dan tipe kecerdasan anak tunarungu, guna meningkatkan kemampuan intelegensi siswanya dan meningkatkan mutu pendidikan di SLB C YPALB Perwari Ancaran Kuningan.

2. Bagi Pengguna, untuk melatih kemampuan kognitif dan emosional serta mengukur berbagai kemungkinan atas bermacam kemampuan anak berkebutuhan khusus tunarungu secara mental dan faktor yang mendukungnya, termasuk prestasi, kepribadian, intelegensi dan tipe kecerdasan, sehingga walaupun mereka anak dengan berkebutuhan khusus namun mereka tetap bisa berfikir dan beraktifitas lebih baik lagi.

\subsection{Metodologi Penelitian dan Teknik Pengumpulan Data}

\subsubsection{Metodologi Penelitian}

Metode pengembangan perangkat lunak yang digunakan dalam penelitian ini adalah RUP (Rational Unified Process). Menurut Salahuddin dan Rosa A.S (2011:105) RUP adalah pendekatan pengembangan perangkat lunak yang dilakukan berulang ulang (iterative), fokus pada arsitektur, lebih diarahkan berdasarkan penggunaan kasus. Dalam RUP terdapat 4 fase yang digunakan, seperti pada gambar 1.1 di bawah ini :

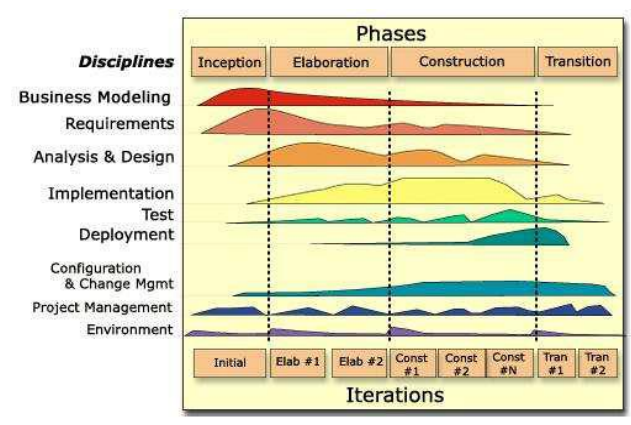

Gambar 1.1 Metode Pengembangan Rational Unified Process (RUP)

Berikut ini penjelasan 4 fase RUP berdasarkan gambar 1.1, yaitu :

1. Inception (permulaan)

Tahap ini mendefinisikan batasan kegiatan, analisis kebutuhan user, melakukan perancangan awal perangkat lunak (perancangan arsitektural dan use case). 
2. Elaboration (perluasan)

Tahap ini lebih di fokuskan pada perencanaan arsitektur sistem, mendeteksi arsitektur sistem yang diinginkan dapat dibuat atau tidak

3. Construction (pembuatan)

Tahap ini merupakan pengimplementasian rancangan perangkat lunak yang telah dibuat, melakukan klarifikasi kebutuhan yang masih tersisa dan melengkapi pembangunan sistem berdasarkan arsitektur yang ditetapkan, secara berulang dan bertambah (iterative and incremental) membangun produk yang lengkap, yang siap dialihkan kepada pengguna.

4. Transition (peralihan)

Tahap ini dilakukan penyerahan perangkat lunak kepada pemakai, melakukan pengujian, pelatihan, setelah digunakan oleh pemakai pemeliharaan perangkat lunak sepenuhnya dilakukan pemakai.

\subsubsection{Teknik Pengumpulan Data}

Untuk mendapatkan data yang diperlukan dalam penelitian, penulis menggunakan beberapa teknik, yaitu:

1. Wawancara

Teknik ini dilakukan melalui wawancara secara lisan dan pertemuan tatap muka dengan sumbernya yaitu SLB C YPALB Perwari Ancaran Kuningan, untuk menghimpun data yang belum tercukupi atau data yang dibutuhkan dalam membangun aplikasi tes kemampuan $I Q$ dan tipe kecerdasan anak tunarungu.

2. Observasi

Teknik ini dilakukan dengan cara mengamati dan melihat langsung dari dekat kegiatan yang sedang berjalan di SLB C YPALB Perwari Ancaran Kuningan untuk melengkapi data yang dibutuhkan dalam membangun aplikasi tes kemampuan $I Q$ dan tipe kecerdasan anak tunarungu.

3. Studi Pustaka

Teknik ini dilakukan untuk menunjang teknik wawancara dan observasi yang telah dilakukan, pengumpulan informasi yang dibutuhkan dilakukan dengan cara mencari referensi-referensi yang berhubungan dengan penelitian yang dilakukan, dapat diperoleh dari buku-buku atau internet.

\section{LANDASAN TEORI}

\subsection{Kajian Teori}

\subsubsection{Intelligence Quotient (IQ)}

Menurut Ahmadi (2009:176), intelek merupakan pikiran, dengan intelek orang dapat menimbang, menguraikan, menghubungkan pengertian satu dengan yang lainnya dan menarik kesimpulan. Inteligensi merupakan kecedasan pikiran, dengan inteligensi fungsi pikir dapat digunakan dengan cepat dan tepat untuk mengatasi suatu situasi atau untuk memecahkan suatu masalah.

Binet dan Simon mendefinisikan inteligensi sebagai kemampuan untuk mengarahkan fikiran atau tindakan, kemampuan untuk mengubah arah tindakan bila tindakan tersebut dilaksanakan, dan kemampuan untuk mengkritik diri sendiri atau melakukan autocriticsm.

\subsubsection{Tes IQ (Intelligence Quotient)}

Dalam Kamus Bahasa Inggris, tes dikatakan berasal dari kata "testum", yang berarti "cawan terbuat dari tanah penguji logam, alat untuk menentukan sesuatu mutu". Tes diartikan sebagai ujian untuk mengukur atau menilai hasil kerja 
(performance), kapabilitas, dan sifat seseorang.

Pada umumnya tes mengandung arti alat untuk menentukan sesuatu atau standar atau ukuran untuk menguji sesuatu. Kaitannya dengan $I Q$, tes merupakan suatu rangkaian persoalan, pertanyaan-pertanyaan, latihan-latihan untuk menentukan tingkat pengetahuan, kemampuan, bakat atau kualifikasi seseorang.

\subsubsection{Tipe Kecerdasan (Mutliple Intelligence)}

Kecerdasan merupakan kemampuan seseorang dalam menghasilkan suatu produk yang berguna bagi dirinya dan orang lain. Sebenarnya manusia memiliki banyak bentuk kecerdasan yang disebut dengan tipe kecerdasan atau kecerdasan majemuk (multiple intelligence). $\mathrm{H}$. Gardner menjelaskan terdapat 8 macam kecerdasan majemuk, yaitu bahasa (linguistic), musik (musical), logikamatematika (logical-mathematical), visual-spasial (visual-spatial), kinestetik-tubuh (bodily-kinesthetic), intrapersonal, interpesonal, naturalis (naturalist).

\subsubsection{Tunarungu}

Dalam Kamus Besar Bahasa Indonesia (2008:105), “Tunarungu adalah tidak dapat mendengar, tuli, mengalami kekurangan, atau kehilangan kemampuan mendengar baik sebagian atau seluruhnya yang diakibatkan karena tidak berfungsinya sebagian atau seluruh alat pendengaran".

Menurut Sutjihati Sumantri (2006:93) "Tunarungu diartikan sebagai suatu keadaan kehilangan pendengaran yang mengakibatkan seseorang tidak dapat menangkap berbagai rangsangan terutama melalui indera pendengarannya".

\subsubsection{Aplikasi}

Menurut Jugiyanto (2005:12) mengemukakan bahwa "Aplikasi adalah penggunaan dalam suatu komputer, instruksi (instruction) atau pernyataan (statememt) yang disusun sedemikian rupa sehingga komputer dapat memproses input (masukan) menjadi output (keluaran)".

\subsection{Android}

Android adalah sistem operasi yang berbasis Linux untuk telepon seluler seperti telepon pintar (smartphone) dan komputer tablet. Android menyediakan platform terbuka bagi para pengembang untuk menciptakan aplikasi mereka sendiri untuk digunakan oleh bermacam peranti begerak.

\subsection{Perancangan Perangkat Lunak} Menurut Salahuddin dan Rosa (2011) Unified Modelling Language (UML) adalah keluarga notasi grafis yang didukung oleh meta-model tunggal, yang membantu pendeskripsian dan desain sistem perangkat lunak, khususnya sistem yang dibangun menggunakan pemrograman berorientasi objek.

\subsection{Tools Perangkat Lunak dan Bahasa Pemrograman \\ Tools perancangan perangkat} lunak yang digunakan dalam penelitian ini yaitu JDK, Android SDK, Android ADT, Android Studio, dan Rational Rose. Sedangkan bahasa pemrograman yang digunakan yaitu Java dan SQLite sebagai databasenya. 


\subsection{Pengujian Perangkat Lunak}

Menurut Roger Pressman (2002: 59-60), "Pengujian perangkat lunak merupakan suatu elemen kritis dari jaminan kualitas perangkat lunak, dimana mempresentasikan kajian pokok dari spesifikasi, desain, dan pengkodean perangkat lunak. Pengujian prangkat lunak dapat dilakukan menggunakan pengujian white box dan black box.

\section{ANALISIS DAN PERANCA- NGAN}

\subsection{Analisis Sistem}

\subsubsection{Analisis Sistem yang sedang berjalan}

Sistem yang berjalan tes $I Q$ untuk anak tunarungu pada SLB C YPALB Perwari Ancaran Kuningan yang dilakukan secara manual, yaitu pada gambar 3.1 di bawah ini :

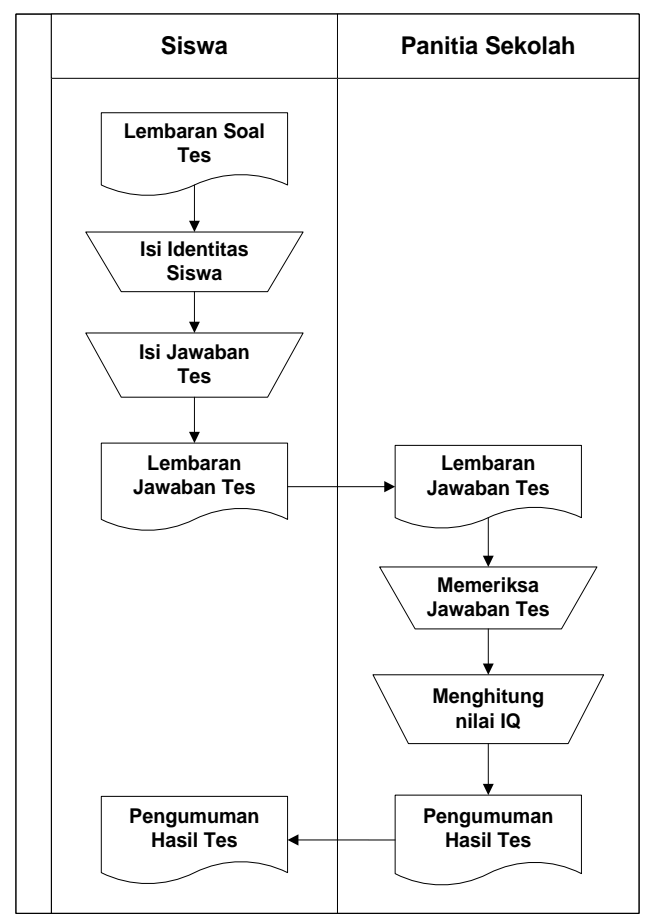

Gambar 3.1 Flowmap Tes $I Q$ yang sedang berjalan

\subsubsection{Analisis Kebutuhan Sistem}

3.1.2.1 Analisis Kebutuhan NonFungsional

1. Kebutuhan Perangkat Keras dan Perangkat Lunak Pembangun Aplikasi

Tabel 3.1 Kebutuhan Perangkat Keras dan Perangkat Lunak Pembangun Aplikasi

\begin{tabular}{|l|l|}
\hline $\begin{array}{c}\text { Perangkat } \\
\text { Keras / Lunak }\end{array}$ & \multicolumn{1}{|c|}{ Spesifikasi } \\
\hline Processor & $\begin{array}{l}\text { Intel Celeron } \mathrm{CPU} \\
\mathrm{N} 28302.16 \mathrm{GHz}\end{array}$ \\
\hline RAM & $2 \mathrm{~GB}$ \\
\hline Harddisk & $500 \mathrm{~GB}$ \\
\hline Sistem Operasi & $\begin{array}{l}\text { Windows 10 Pro } \\
32 \text { bit }\end{array}$ \\
\hline $\begin{array}{l}\text { Bahasa } \\
\text { Pemrograman }\end{array}$ & $\begin{array}{l}\text { Java (Framework } \\
\text { Android) }\end{array}$ \\
\hline $\begin{array}{l}\text { Integrated } \\
\text { Development } \\
\text { Environment }\end{array}$ & $\begin{array}{l}\text { Android Studio } \\
2.2 .3\end{array}$ \\
\hline Emulator & Genymotion 2.8 \\
\hline
\end{tabular}

2. Kebutuhan Minimal Perangkat Keras dan Perangkat Lunak Implementasi Aplikasi Tabel 3.2 Kebutuhan Minimal Perangkat Keras dan Perangkat Lunak Implementasi Aplikasi

\begin{tabular}{|l|l|}
\hline \multicolumn{1}{|c|}{$\begin{array}{c}\text { Perangkat } \\
\text { Keras / Lunak }\end{array}$} & \multicolumn{1}{|c|}{ Spesifikasi } \\
\hline Sistem Operasi & $\begin{array}{l}\text { Android dengan } \\
\text { versi API:16 }\end{array}$ \\
\hline $\begin{array}{l}\text { RAM } \\
\text { (Memori) }\end{array}$ & $512 \mathrm{MB}$ \\
\hline Layar & $3.5 \%$ \\
\hline
\end{tabular}




\subsection{Pengujian Metode Pemecahan Masalah}

\subsubsection{Metode Binet Simon}

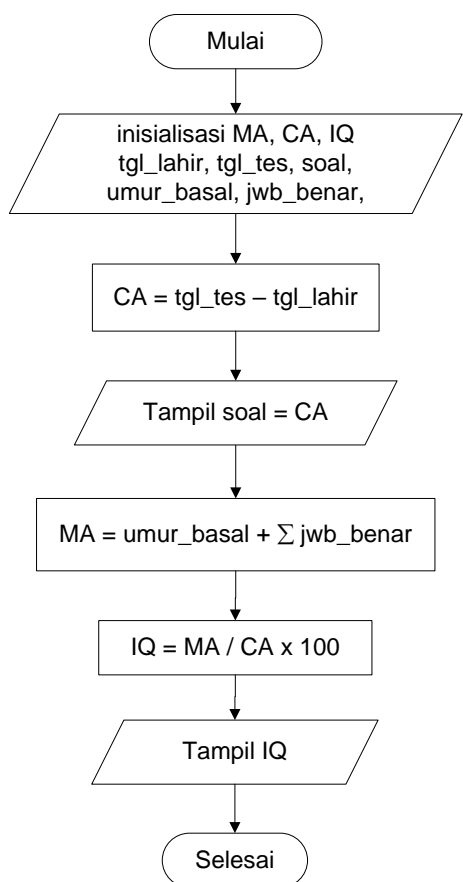

Gambar 3.2 Flowchart Perhitungan $I Q$ Metode Binet Simon

\subsubsection{Metode Fuzzy Logic}

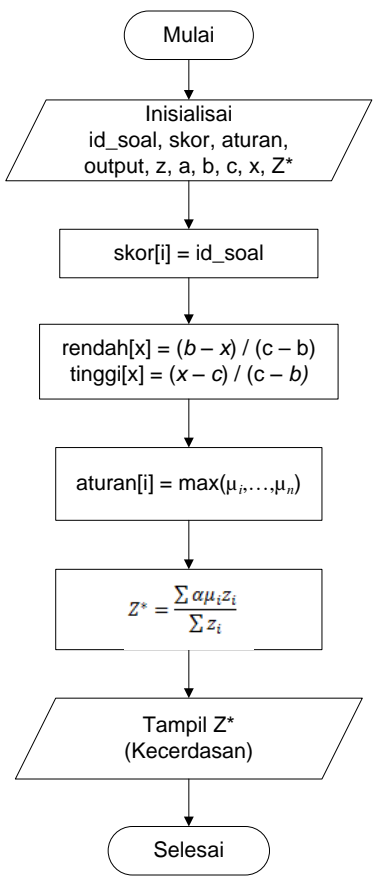

Gambar 3.3 Flowchart Menentukan Tipe Kecerdasan Metode Fuzzy Logic

\subsection{Perancangan Sistem}

\subsubsection{Use Case Diagram}

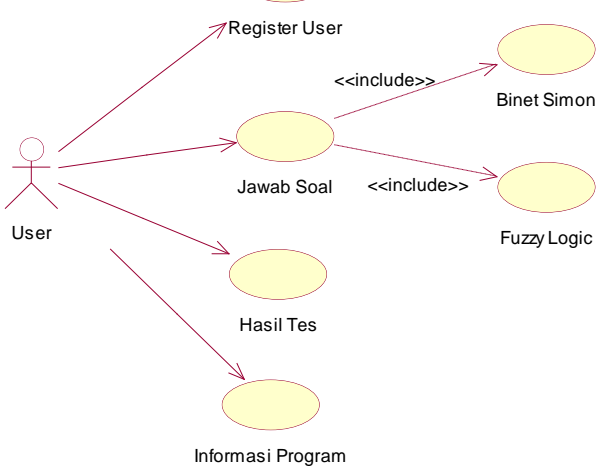

Gambar 3.5 Use Case Diagram Aplikasi Tes $I Q$ dan Tipe Kecerdasan Menggunakan Metode Binet Simon dan Metode Fuzzy Logic

\subsubsection{Skenario Use Case Diagram}

\subsubsection{Skenario Use Case Jawab} Soal

Skenario use case jawab soal berfungsi untuk menampilkan soalsoal tes $I Q$, selanjutnya akan dijawab user untuk mengetahui nilai $I Q$ dan tipe kecerdasan.

Tabel 3.6 Skenario Use Case Jawab Soal

\begin{tabular}{|l|l|}
\hline \multicolumn{2}{|c|}{ Identifikasi } \\
\hline Nama & Jawab Soal \\
\hline Tujuan & $\begin{array}{l}\text { Menjawab soal-soal tes } I Q \\
\text { untuk mengetahui nilai } I Q \\
\text { dan tipe kecerdasan } \text { user }\end{array}$ \\
\hline \multicolumn{2}{|c|}{ Deskripsi } \\
\hline Aktor & Pengguna user) \\
\hline \multicolumn{2}{|c|}{ Skenario Use Case } \\
\hline $\begin{array}{l}\text { Kondisi Awal } \\
\text { (PreCondition) }\end{array}$ & $\begin{array}{l}\text { Aktor telah memasuk- } \\
\text { kan nama dan tanggal } \\
\text { lahir }\end{array}$ \\
\hline $\begin{array}{l}\text { Aksi Aktor } \\
\text { Reaksi Sistem }\end{array}$ \\
\hline $\begin{array}{l}\text { Telah memasuk- } \\
\text { kan nama dan } \\
\text { tanggal lahir }\end{array}$ & $\begin{array}{l}\text { Menampilkan soal- } \\
\text { soal tes } I Q\end{array}$ \\
\hline $\begin{array}{l}\text { Menjawab } \\
\text { soal-soal tes } I Q\end{array}$ & $\begin{array}{l}\text { Memeriksa jawaban } \\
\text { tes } I Q\end{array}$ \\
\hline
\end{tabular}




\begin{tabular}{|l|l|}
\hline & $\begin{array}{l}\text { Menghitung nilai IQ } \\
\text { menggunakan metode } \\
\text { binet simon }\end{array}$ \\
\hline $\begin{array}{l}\text { Menghitung nilai tipe } \\
\text { kecerdasan mengguna- } \\
\text { kan metode fuzzy logic }\end{array}$ \\
\hline $\begin{array}{l}\text { Menyimpan nilai IQ } \\
\text { dan nilai tipe } \\
\text { kecerdasan }\end{array}$ \\
\hline $\begin{array}{l}\text { Menampilkan nilai IQ } \\
\text { dan tipe kecerdasan }\end{array}$ \\
\hline $\begin{array}{l}\text { Kondisi Akhir } \\
\text { (Post }\end{array}$ & $\begin{array}{l}\text { Jika berhasil sistem } \\
\text { akan menampilkan } \\
\text { nama, jumlah jawaban } \\
\text { benar, nilai IQ, klasi- } \\
\text { fi-kasi kecerdasan, dan } \\
\text { tipe kecerdasan } \text { user }\end{array}$ \\
\cline { 2 - 2 } $\begin{array}{l}\text { Jika gagal sistem akan } \\
\text { kembali ke halaman } \\
\text { menu utama. }\end{array}$ \\
\hline
\end{tabular}

\subsubsection{Activity Diagram}

\subsubsection{Activity Diagram Jawab Soal}

Activity diagram jawab soal merupakan aktivitas user dalam menjawab soal-soal tes $I Q$ untuk mengetahui nilai $I Q$ dan tipe kecerdasan, yaitu dapat dilihat pada gambar 3.7 di bawah ini :

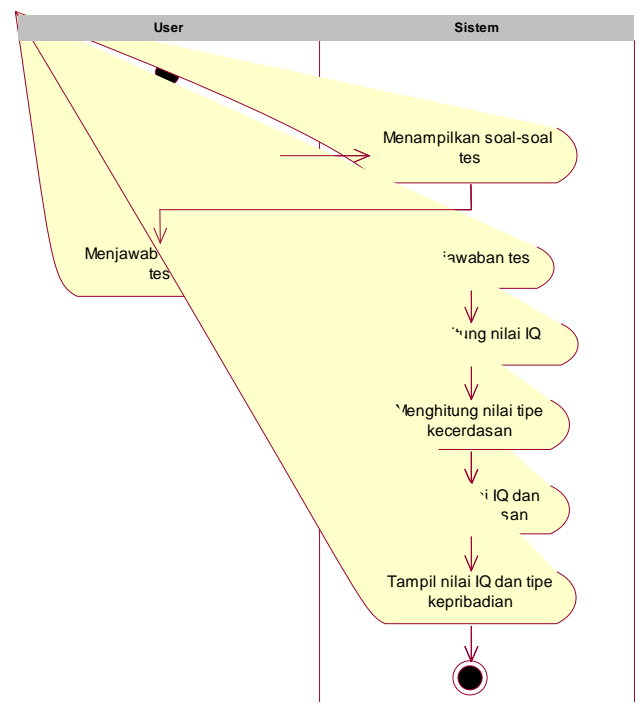

Gambar 3.7 Activity Diagram Jawab Soal

\subsubsection{Class Diagram}

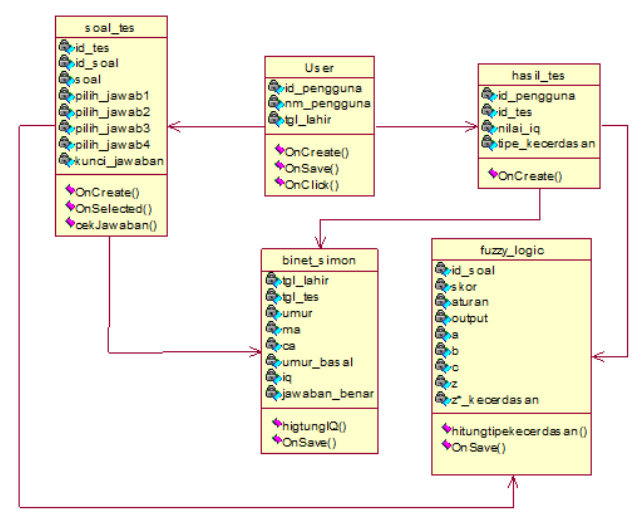

Gambar 3.11 Class Diagram Aplikasi Tes $I Q$ dan Tipe Kecerdasan Menggunakan Metode Binet Simon dan Metode Fuzzy Logic

\subsubsection{Sequence Diagram}

\subsubsection{Sequence Diagram Jawab Soal}

Sequence diagram jawab soal merupakan skenario user dalam menjawab soal-soal tes $I Q$ setelah memasukkan nama dan tanggal lahir untuk mengetahui nilai $I Q$ dan tipe kecerdasan, yaitu dapat dilihat pada gambar 3.13 di bawah ini :

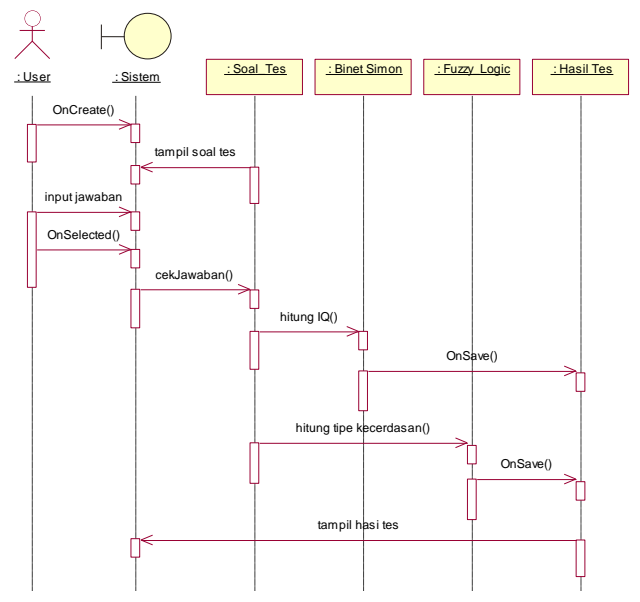

Gambar 3.13 Squence Diagram Jawab Soal 


\subsection{Perancangan Antarmuka}

\subsubsection{Halaman Utama (Home)}

Halaman utama (home) terdiri dari beberapa menu diantaranya menu mulai tes $I Q$, hasil tes $I Q$, bantuan, tentang, dan keluar, untuk rancangan halamannya dapat dilihat pada gambar 3.17 di bawah ini :

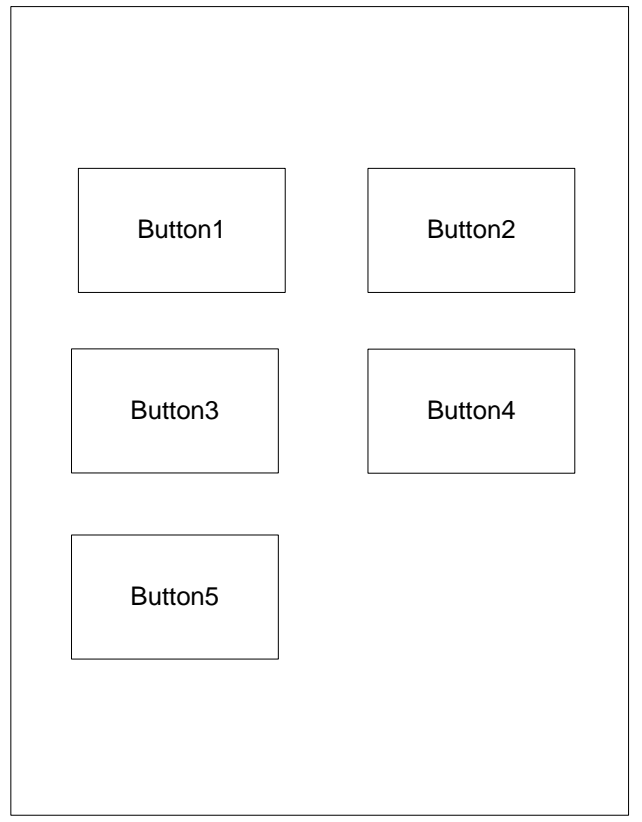

Gambar 3.17 Halaman Utama (Home)

Komponen dalam rancangan halaman utama (home) dapat dilihat pada tabel 3.9 di bawah ini :

Tabel 3.9 Komponen Halaman Utama (Home)

\begin{tabular}{|l|l|}
\hline Komponen & \multicolumn{1}{|c|}{ Keterangan } \\
\hline Button1 & Mulai Tes $I Q$ \\
\hline Button2 & Hasil Tes $I Q$ \\
\hline Button3 & $\begin{array}{l}\text { Bantuan pengguna- } \\
\text { an aplikasi }\end{array}$ \\
\hline Button4 & $\begin{array}{l}\text { Tentang pembuat } \\
\text { dan aplikasi }\end{array}$ \\
\hline Button5 & Keluar dari aplikasi \\
\hline
\end{tabular}

\section{HASIL DAN PEMBAHASAN \\ 4.1 Pengujian Sistem \\ 4.1.1 Pengujian Black-Box \\ 1. Halaman Mulai Tes}

Test IQ dan Tipe Kecerdasan Test IQ dan Tipe Kecerdasan

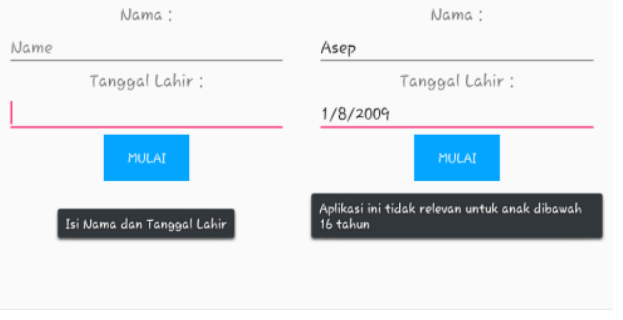

Gambar 4.1 Halaman Mulai Tes

Berdasarkan gambar 4.1 di atas, dapat disimpulkan bahwa pengujian black-box halaman mulai tes berhasil yaitu pada tabel 4.1 di bawah ini :

Tabel 4.1 Pengujian Halaman Mulai Tes

\begin{tabular}{|c|c|c|c|}
\hline $\begin{array}{c}\text { Data } \\
\text { Masukkan }\end{array}$ & \begin{tabular}{|c|} 
Yang \\
diharapkan
\end{tabular} & Pengamatan & $\begin{array}{l}\text { Kesim- } \\
\text { pulan }\end{array}$ \\
\hline $\begin{array}{l}\text { Memasuk } \\
\text {-kan } \\
\text { nama dan } \\
\text { tanggal } \\
\text { lahir }\end{array}$ & $\begin{array}{l}\text { Akan } \\
\text { menampil- } \\
\text { kan soal tes, } \\
\text { nama dan } \\
\text { nilai } I Q\end{array}$ & $\begin{array}{l}\text { Menampil- } \\
\text { kan soal tes, } \\
\text { nama dan } \\
\text { nilai } I Q\end{array}$ & $\begin{array}{l}\text { [Error! } \\
\text { Referenc } \\
\text { e source } \\
\text { not } \\
\text { found.] } \\
\text { Diterima } \\
\text { [ ] } \\
\text { Ditolak }\end{array}$ \\
\hline $\begin{array}{l}\text { Tidak } \\
\text { memasuk } \\
\text {-kan } \\
\text { nama dan } \\
\text { tanggal } \\
\text { lahir }\end{array}$ & $\begin{array}{l}\text { Akan } \\
\text { menampil- } \\
\text { kan pesan } \\
\text { "Isi Nama } \\
\text { dan } \\
\text { Tanggal } \\
\text { Lahir" }\end{array}$ & $\begin{array}{l}\text { Menampil- } \\
\text { kan pesan } \\
\text { "Isi Nama } \\
\text { dan } \\
\text { Tanggal } \\
\text { Lahir" }\end{array}$ & $\begin{array}{l}\text { [Error! } \\
\text { Referenc } \\
\text { e source } \\
\text { not } \\
\text { found.] } \\
\text { Diterima } \\
\text { [ ] } \\
\text { Ditolak }\end{array}$ \\
\hline $\begin{array}{l}\text { Memasuk- } \\
\text { kan } \\
\text { tanggal } \\
\text { lahir } \\
\text { kurang } \\
\text { dari } \\
16 \text { tahun }\end{array}$ & $\begin{array}{l}\text { Akan } \\
\text { menampil- } \\
\text { kan pesan } \\
\text { "Aplikasi ini } \\
\text { tidak relevan } \\
\text { untuk anak } \\
\text { dibawah } 16 \\
\text { tahun" }\end{array}$ & $\begin{array}{l}\text { Menampil- } \\
\text { kan pesan } \\
\text { "Aplikasi ini } \\
\text { tidak relevan } \\
\text { untuk anak } \\
\text { dibawah } 16 \\
\text { tahun" }\end{array}$ & $\begin{array}{l}\text { [Error! } \\
\text { Referenc } \\
\text { e source } \\
\text { not } \\
\text { found.] } \\
\text { Diterima } \\
\text { [ ] } \\
\text { Ditolak }\end{array}$ \\
\hline
\end{tabular}




\section{Halaman Tes $I Q$}

Tabel 4.2 Pengujian Halaman Tes $I Q$

\begin{tabular}{|c|c|c|c|}
\hline $\begin{array}{c}\text { Data } \\
\text { Masukkan }\end{array}$ & $\begin{array}{c}\text { Yang } \\
\text { diharapkan }\end{array}$ & Pengamatan & $\begin{array}{c}\text { Kesim- } \\
\text { pulan }\end{array}$ \\
\hline $\begin{array}{l}\text { Memilih } \\
\text { salah satu } \\
\text { jawaban }\end{array}$ & $\begin{array}{l}\text { Akan } \\
\text { menampilkan } \\
\text { soal } \\
\text { berikutnya }\end{array}$ & $\begin{array}{l}\text { Menampil- } \\
\text { kan soal } \\
\text { berikutnya }\end{array}$ & $\begin{array}{l}\text { [Error! } \\
\text { Referen } \\
\text { ce } \\
\text { source } \\
\text { not } \\
\text { found.] } \\
\text { Diterima } \\
\text { [ ] } \\
\text { Ditolak }\end{array}$ \\
\hline $\begin{array}{l}\text { Tidak } \\
\text { memilih } \\
\text { salah satu } \\
\text { jawaban }\end{array}$ & $\begin{array}{l}\text { Akan } \\
\text { menampilkan } \\
\text { pesan "Pilih } \\
\text { Jawaban } \\
\text { Anda!" }\end{array}$ & $\begin{array}{l}\text { Menampil- } \\
\text { kan pesan } \\
\text { "Pilih } \\
\text { Jawaban } \\
\text { Anda!" }\end{array}$ & $\begin{array}{l}\text { [Error! } \\
\text { Referen } \\
\text { ce } \\
\text { source } \\
\text { not } \\
\text { found.] } \\
\text { Diterima } \\
\text { [ ] } \\
\text { Ditolak }\end{array}$ \\
\hline $\begin{array}{l}\text { Menjawab } \\
\text { semua soal }\end{array}$ & $\begin{array}{l}\text { Akan } \\
\text { menampilkan } \\
\text { nama, } \\
\text { jawaban } \\
\text { benar, nilai } \\
I Q, \text { klasifikas } \\
I Q \text { dan tipe } \\
\text { kecerdasan }\end{array}$ & $\begin{array}{l}\text { Menampil- } \\
\text { kan nama, } \\
\text { jawaban } \\
\text { benar, nilai } \\
I Q, \\
\text { klasifikasi } \\
I Q \text { dan tipe } \\
\text { kecerdasan }\end{array}$ & $\begin{array}{l}\text { [Error! } \\
\text { Referen } \\
\text { ce } \\
\text { source } \\
\text { not } \\
\text { found.] } \\
\text { Diterima } \\
\text { [ ] } \\
\text { Ditolak }\end{array}$ \\
\hline $\begin{array}{l}\text { Memilih } \\
\text { kembali ke } \\
\text { menu } \\
\text { utama }\end{array}$ & $\begin{array}{l}\text { Akan } \\
\text { menampilkan } \\
\text { menu utama }\end{array}$ & $\begin{array}{l}\text { Menampil- } \\
\text { kan menu } \\
\text { utama }\end{array}$ & $\begin{array}{l}\text { [Error! } \\
\text { Referen } \\
\text { ce } \\
\text { source } \\
\text { not } \\
\text { found.] } \\
\text { Diterima } \\
\text { [ ] } \\
\text { Ditolak }\end{array}$ \\
\hline
\end{tabular}

\section{Halaman Menu Tes}

Tabel 4.3 Pengujian Halaman Menu Tes

\begin{tabular}{|l|l|l|l|}
\hline $\begin{array}{c}\text { Data } \\
\text { Masukkan }\end{array}$ & \multicolumn{1}{|c|}{$\begin{array}{c}\text { Yang } \\
\text { diharapkan }\end{array}$} & Pengamatan & $\begin{array}{l}\text { Kesim- } \\
\text { pulan }\end{array}$ \\
\hline $\begin{array}{l}\text { Memilih } \\
\text { menu Hasil } \\
\text { Tes }\end{array}$ & $\begin{array}{l}\text { Akan } \\
\text { menampil- } \\
\text { kan nama } \\
\text { dan nilai } I Q\end{array}$ & $\begin{array}{l}\text { Menampil- } \\
\text { kan nama } \\
\text { dan nilai } I Q\end{array}$ & $\begin{array}{l}{[\text { Error! }} \\
\text { Referen } \\
\text { ce } \\
\text { source } \\
\text { not } \\
\text { found. }\end{array}$ \\
\hline
\end{tabular}

\begin{tabular}{|l|l|l|}
\hline & & $\begin{array}{l}\text { Diterima } \\
{[\quad]} \\
\text { Ditolak }\end{array}$ \\
\hline
\end{tabular}

4. Halaman Bantuan

Tabel 4.4 Pengujian Halaman Bantuan

\begin{tabular}{|c|c|c|c|}
\hline $\begin{array}{c}\text { Data } \\
\text { Masukkan }\end{array}$ & $\begin{array}{c}\text { Yang } \\
\text { diharapkan }\end{array}$ & Pengamatan & $\begin{array}{c}\text { Kesim } \\
\text { pulan }\end{array}$ \\
\hline $\begin{array}{l}\text { Memilih } \\
\text { menu } \\
\text { Bantuan }\end{array}$ & $\begin{array}{l}\text { Akan } \\
\text { menampil- } \\
\text { kan menu } \\
\text { klasifikasi } \\
\text { kecerdasan } \\
\text { dan } \\
\text { tipe } \\
\text { kepribadian }\end{array}$ & $\begin{array}{l}\text { Menampil- } \\
\text { kan menu } \\
\text { klasifikasi } \\
\text { kecerdasan } \\
\text { dan tipe } \\
\text { kepribadian }\end{array}$ & $\begin{array}{l}\text { [Error! } \\
\text { Referen } \\
\text { ce } \\
\text { source } \\
\text { not } \\
\text { found.] } \\
\text { Diterima } \\
{[\quad]} \\
\text { Ditolak }\end{array}$ \\
\hline $\begin{array}{l}\text { Memilih } \\
\text { menu } \\
\text { Klasifikasi } \\
\text { Kecerdasan }\end{array}$ & $\begin{array}{l}\text { Akan } \\
\text { menampil- } \\
\text { kan } \\
\text { klasifikasi } \\
\text { kecerdasan }\end{array}$ & $\begin{array}{l}\text { Menampil- } \\
\text { kan } \\
\text { klasifikasi } \\
\text { kecerdasan }\end{array}$ & $\begin{array}{l}\text { [Error! } \\
\text { Referen } \\
\text { ce } \\
\text { source } \\
\text { not } \\
\text { found.] } \\
\text { Diterima } \\
{[\quad]} \\
\text { Ditolak }\end{array}$ \\
\hline $\begin{array}{l}\text { Memilih } \\
\text { menu Tipe } \\
\text { Kecerdasan }\end{array}$ & $\begin{array}{l}\text { Akan } \\
\text { menampil- } \\
\text { kan klasifi- } \\
\text { kasi tipe } \\
\text { kepribadian }\end{array}$ & $\begin{array}{l}\text { Menampilka } \\
\text { n klasifikasi } \\
\text { tipe } \\
\text { kepribadian }\end{array}$ & $\begin{array}{l}\text { [Error! } \\
\text { Referen } \\
\text { ce } \\
\text { source } \\
\text { not } \\
\text { found.] } \\
\text { Diterima } \\
{[\quad]} \\
\text { Ditolak }\end{array}$ \\
\hline
\end{tabular}

\section{Halaman Tentang}

Tabel 4.5 Pengujian Halaman Tentang

\begin{tabular}{|l|l|l|l|}
\hline $\begin{array}{c}\text { Data } \\
\text { Masukkan }\end{array}$ & \multicolumn{1}{|c|}{$\begin{array}{c}\text { Yang } \\
\text { diharapkan }\end{array}$} & Pengamatan & $\begin{array}{l}\text { Kesim- } \\
\text { pulan }\end{array}$ \\
\hline $\begin{array}{l}\text { Memilih } \\
\text { menu } \\
\text { Tentang }\end{array}$ & $\begin{array}{l}\text { Akan } \\
\text { menampilkan } \\
\text { informasi } \\
\text { pembuat } \\
\text { aplikasi }\end{array}$ & $\begin{array}{l}\text { Menampilkan } \\
\text { informasi } \\
\text { pembuat } \\
\text { aplikasi }\end{array}$ & $\begin{array}{l}\text { [Error! } \\
\text { Referen } \\
\text { ce } \\
\text { source } \\
\text { not } \\
\text { found.] } \\
\text { Diterima } \\
\text { [ ] }\end{array}$ \\
& & & Ditolak \\
\hline
\end{tabular}




\section{Menu Keluar}

Tabel 4.6 Pengujian Menu Keluar

\begin{tabular}{|l|l|l|l|}
\hline $\begin{array}{c}\text { Data } \\
\text { Masukkan }\end{array}$ & \multicolumn{1}{|c|}{$\begin{array}{c}\text { Yang } \\
\text { diharapkan }\end{array}$} & Pengamatan & $\begin{array}{l}\text { Kesim- } \\
\text { pulan }\end{array}$ \\
\hline $\begin{array}{l}\text { Memilih } \\
\text { menu } \\
\text { Keluar }\end{array}$ & $\begin{array}{l}\text { Akan } \\
\text { menampil- } \\
\text { kan pesan } \\
\text { "Apakah } \\
\text { yakin akan } \\
\text { keluar? Ya } \\
\text { atau Tidak" }\end{array}$ & $\begin{array}{l}\text { Menampil- } \\
\text { kan pesan } \\
\text { "Apakah } \\
\text { yakin akan } \\
\text { keluar? Ya } \\
\text { atau Tidak" }\end{array}$ & $\begin{array}{l}\text { [Error! } \\
\text { Referenc } \\
\text { e source } \\
\text { not } \\
\text { found.] } \\
\text { Diterima } \\
\text { [ ] } \\
\text { Ditolak }\end{array}$ \\
\hline $\begin{array}{l}\text { Memilih } \\
\text { Ya }\end{array}$ & $\begin{array}{l}\text { Akan keluar } \\
\text { dari aplikasi }\end{array}$ & $\begin{array}{l}\text { Keluar dari } \\
\text { aplikasi }\end{array}$ & $\begin{array}{l}\text { [Error! } \\
\text { Referenc } \\
\text { e source } \\
\text { not } \\
\text { found. }] \\
\text { Diterima } \\
\text { [ ] } \\
\text { Ditolak }\end{array}$ \\
\hline $\begin{array}{l}\text { Memilih } \\
\text { Tidak }\end{array}$ & $\begin{array}{l}\text { Akan } \\
\text { menampil- } \\
\text { kan menu } \\
\text { utama }\end{array}$ & $\begin{array}{l}\text { Menampil- } \\
\text { kan menu } \\
\text { utama }\end{array}$ & $\begin{array}{l}\text { [Error! } \\
\text { Referenc } \\
\text { e source } \\
\text { not } \\
\text { found.] } \\
\text { Diterima } \\
\text { [ [ ] } \\
\text { Ditolak }\end{array}$ \\
\hline
\end{tabular}




\subsubsection{Pengujian White-Box}

Tabel 4.7 Pengujian White-Box Metode Binet Simon

\begin{tabular}{|c|c|}
\hline Line & Syntax \\
\hline 1 & $\begin{array}{l}\text { public class ResultActivity } \\
\text { extends AppCompatActivity }\{ \\
\text { public int } \\
\text { getDifferenceDate() } \\
\text { User user = } \\
\text { GlobalVariables.getInstance () } \\
\text {-user; } \\
\text { Calendar birthdate = } \\
\text { Calendar.getInstance (); } \\
\text { birthdate.set (user.getYear(), } \\
\text { user.getMonth(), } \\
\text { user.getDate()); } \\
\text { Calendar now = } \\
\text { Calendar.getInstance (); } \\
\text { int year = } \\
\text { now.get (Calendar.YEAR) - } \\
\text { birthdate.get (Calendar.YEAR); } \\
\text { int month = 0; }\end{array}$ \\
\hline 2 & $\begin{array}{l}\text { if (birthdate.get (Calendar.MON } \\
\text { TH) > now.get (Calendar.MONTH) } \\
\text { \&\& } \\
\text { birthdate.get (Calendar.DATE) } \\
>\text { now.get (Calendar.DATE) ) } \\
\text { month = } \\
\text { now.get (Calendar.MONTH) - } \\
\text { birthdate.get (Calendar.MONTH) } \\
; \\
\text {; }\end{array}$ \\
\hline 3 & $\begin{array}{l}\text { else }\{ \\
\text { month }=12+ \\
\text { (now.get (Calendar.MONTH) - } \\
\text { birthdate.get (Calendar.MONTH) } \\
\text { ); } \\
\}\end{array}$ \\
\hline 4 & $\begin{array}{l}\text { Question } q= \\
\text { paket.get (currento10); } \\
\text { int index = current - } 1 ;\end{array}$ \\
\hline 5 & $\begin{array}{l}\text { public String } \\
\text { getClassificationIQ(int iq) }\end{array}$ \\
\hline 6 & $\begin{array}{l}\text { if }(\text { iq }>=140) \\
\text { return "Genius"; } \\
\text { \} }\end{array}$ \\
\hline 7 & $\begin{array}{l}\text { else if }(i q<140 \text { \&\& iq }>129) \\
\{ \\
\text { return "Sangat Cerdas"; } \\
\}\end{array}$ \\
\hline 8 & $\begin{array}{l}\text { else if }(\text { iq }<130 \text { \&\& iq }>119) \\
\{ \\
\text { return "Cerdas"; }\end{array}$ \\
\hline 9 & $\begin{array}{l}\text { else if }(i q<120 \text { \&\& iq }>110) \\
\{ \\
\text { return "Diatas Rata-rata"; } \\
\}\end{array}$ \\
\hline 10 & $\begin{array}{l}\text { else if (iq }<111 \text { \&\& iq }>90) \\
\{ \\
\text { return "Rata-rata atau } \\
\text { Normal"; } \\
\}\end{array}$ \\
\hline
\end{tabular}

\begin{tabular}{|c|c|}
\hline Line & Syntax \\
\hline 11 & $\begin{array}{l}\text { else if }(i q<91 \& \& \text { iq }>79) \\
\text { return "Dibawah Rata-rata"; } \\
\text { \} }\end{array}$ \\
\hline 12 & $\begin{array}{l}\text { else if }(i q<80 \& \& \text { iq }>69) \\
\text { return "Bodoh atau Garis } \\
\text { Batas"; } \\
\text { \} }\end{array}$ \\
\hline 13 & $\begin{array}{l}\text { else if (iq }<70 \text { \&\& iq }>49) \\
\text { return "Moron atau Lemah } \\
\text { Berfikir"; } \\
\text { \} }\end{array}$ \\
\hline 14 & $\begin{array}{l}\text { else if }(i q<50 \& \& \text { iq }>29) \\
\text { return "Pander"; } \\
\}\end{array}$ \\
\hline 15 & $\begin{array}{l}\text { else }\{ \\
\text { return "Cacat Otak"; } \\
\}\end{array}$ \\
\hline 16 & $\begin{array}{l}\text { \} } \\
\text { txtRightAnswer.setText ("Jawaba } \\
\text { n Benar : } \\
\text { "+GlobalVariables.getInstance ( } \\
\text { ).rightAnswer); } \\
\text { txtIQ.setText("IQ Anda : } \\
\text { "+iq); } \\
\text { txtStatus.setText ("Klasifikas } \\
\text { i : } \\
\text { "+getClassificationIQ(iq)); } \\
\text { \} }\end{array}$ \\
\hline
\end{tabular}

Berdasarkan tabel 4.7 di atas, maka dapat dibuat suatu bentuk flowgraph pengujian white-box metode Binet Simon seperti pada gambar 4.7 di bawah ini :

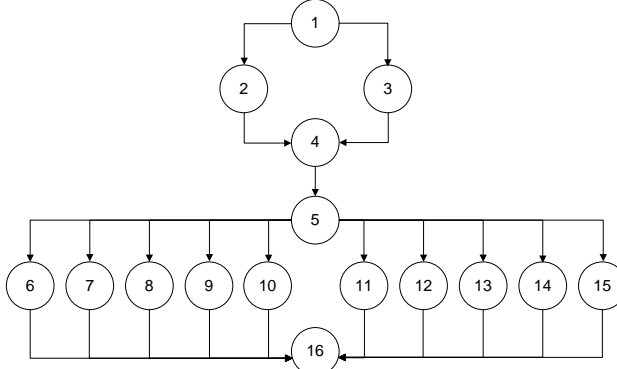

Gambar 4.7 Flow Graph Pengujian White-Box Metode Bine Simon

Berdasarkan gambar flowgraph 4.7 di atas, maka dapat dilakukan langkah perhitungan nilai Cyclmetic Complexity Graph yaitu menggunakan rumus di bawah ini :

$$
V(G)=R=E-N+2=P+1
$$

1. Penentuan nilai-nilai dalam rumus Cyclmetic Complexity Graph a. Jumlah region $(\mathrm{R})=11$ 
b. Jumlah edge $(\mathrm{E})=25$

c. Jumlah node $(\mathrm{N})=16$

d. Jumlah decision $(\mathrm{P})=10$

2. Perhitungan Nilai Cyclmetic Complexity Graph

a. $V(G)=R=11$

b. $V(G)=E-N+2=34-25+2$ $=11$

c. $V(G)=P+1=10+1=11$

Jadi, dapat disimpulkan nilai Cyclmetic Complexity Graph adalah 11.

3. Penentuan Alur (path)

Berdasarkan perhitungan di atas, diketahui nilai Cyclmetic Complexity Graph adalah 11, maka terdapat 11 path, yaitu:
a. Path $1=1-2-3-4-5-6-16$
b. Path2 = 1-2-3-4-5-7-16
c. Path3 = 1-2-3-4-5-8-16
d. Path $4=1-2-3-4-5-9-16$
e. Path5 = 1-2-3-4-5-10-16
f. Path6 = 1-2-3-4-5-11-16
g. Path $7=1-2-3-4-5-12-16$
h. Path $8=1-2-3-4-5-13-16$
i. Path $9=1-2-3-4-5-14-16$
j. Path $10=1-2-3-4-5-15-16$
k. Path $11=1-3-4-5-6-16$

\subsection{Manual Program}

\subsubsection{Halaman Menu Utama}
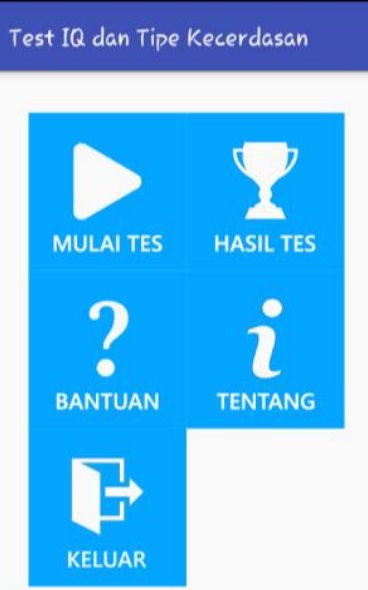

Gambar 4.8 Halaman Menu Utama

\subsubsection{Halaman Menu Mulai Tes}

1. Halaman Register User

\section{Test IQ dan Tipe Kecerdasan}

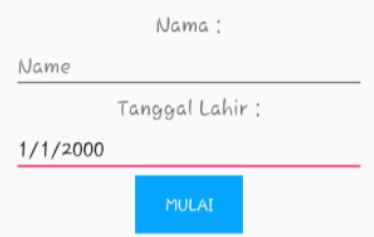

Gambar 4.9 Halaman Register User

2. Halaman Soal Tes

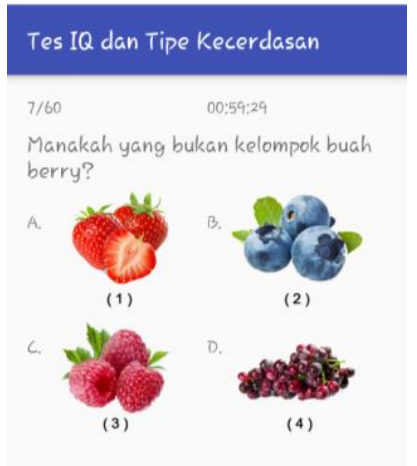

\section{SELANJUTNYA}

Gambar 4.10 Halaman Soal Tes

3. Halaman Hasil Tes

\section{Tes $I Q$ dan Tipe Kecerdasan}

Yogi Sanhari

Jawaban Benar : 56

IQ Anda : 108

Klasifikasi: rata-rata atau Normal

Tipe Kecerdasan: Interpersonal

KEMBALI KE MENU

Gambar 4.11 Halaman Hasil Tes 


\subsubsection{Halaman Menu Hasil Tes}

Tes IQ dan Tipe Kecerdasan

$\begin{array}{lll}\text { No Nama } & \text { IQ } & \begin{array}{l}\text { Kecerdasa } \\ n\end{array} \\ \begin{array}{l}1 \text { Yogi } \\ \text { Sanhari }\end{array} & 108 & \begin{array}{l}\text { Interperson } \\ \text { al }\end{array}\end{array}$

Gambar 4.12 Halaman Menu Hasil Tes

\subsubsection{Halaman Menu Bantuan}

Test $I Q$ dan Tipe Kecerdasan

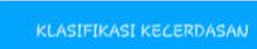

TIPE KECERDASAN

Gambar 4.13 Halaman Menu Bantuan

1. Halaman Klasifikasi $I Q$

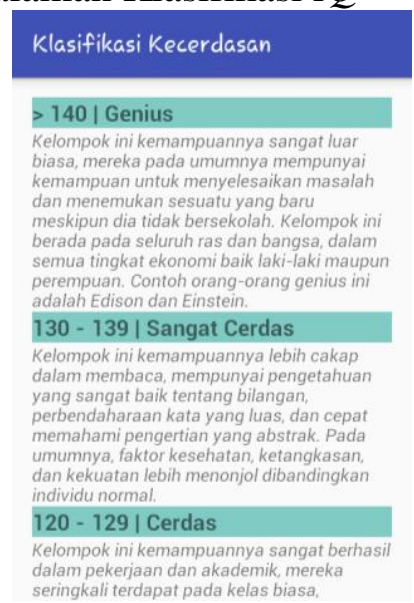

Gambar 4.14 Halaman Klasifikasi IQ
2. Halaman Klasifikasi Tipe Kecerdasan

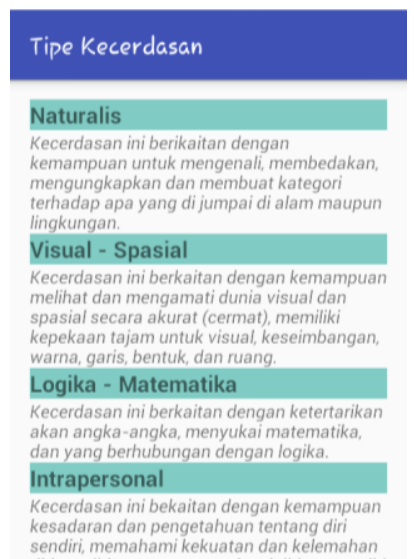

Gambar 4.15 Halaman Klasifikasi Tipe Kecerdasan

\subsubsection{Halaman Menu Tentang}

\section{Tentang Saya}

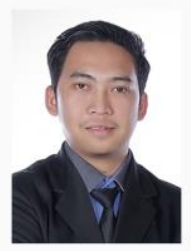

YOGI SANHARI

NIM 2012081158

Teknik Informatika (S1)

Fakultas Ilmu Komputer

Universitas Kuningan

Copyright (c) 20161 Yogi Sanhari

Gambar 4.16 Halaman Tentang

\subsection{Hasil Penelitian}

\subsubsection{Pengguna (User) Tunarungu}

Berdasarkan penyebaran kuesioner penggunaan aplikasi kepada pengguna (user) yaitu anak tunarungu SLB C YPALB Perwari Ancaran Kuningan diperoleh data sebagai berikut :

Tabel 4.8 Data Pengguna (User)

\begin{tabular}{|c|c|c|c|c|l|}
\multicolumn{7}{|c}{ Tunarungu } \\
\hline No & Nama & $\begin{array}{c}\text { Tgl. } \\
\text { Lahir }\end{array}$ & $\begin{array}{c}\text { Jwbnn } \\
\text { Benar }\end{array}$ & $\boldsymbol{I Q}$ & $\begin{array}{l}\text { Tipe Ke- } \\
\text { cerdasan }\end{array}$ \\
\hline 1 & Lia N & $\begin{array}{r}10-05- \\
1999\end{array}$ & 37 & 106 & $\begin{array}{l}\text { Interper- } \\
\text { sonal }\end{array}$ \\
\hline
\end{tabular}




\begin{tabular}{|c|l|c|c|c|l|}
\hline No & Nama & $\begin{array}{c}\text { Tgl. } \\
\text { Lahir }\end{array}$ & $\begin{array}{c}\text { Jwbn } \\
\text { Benar }\end{array}$ & $\boldsymbol{I Q}$ & $\begin{array}{l}\text { Tipe Ke- } \\
\text { cerdasan }\end{array}$ \\
\hline 2 & Dian N & $\begin{array}{c}23-10- \\
1998\end{array}$ & 41 & 112 & $\begin{array}{l}\text { Interper- } \\
\text { sonal }\end{array}$ \\
\hline 3 & $\begin{array}{l}\text { Gilang } \\
\text { S }\end{array}$ & $\begin{array}{c}08-12- \\
1998\end{array}$ & 28 & 96 & $\begin{array}{l}\text { Intraper- } \\
\text { sonal }\end{array}$ \\
\hline 5 & Ylfi A & $\begin{array}{c}07-01- \\
2000\end{array}$ & 19 & 97 & $\begin{array}{l}\text { Intraper- } \\
\text { sonal }\end{array}$ \\
\hline 6 & Sindi N & $\begin{array}{c}28-11- \\
1998\end{array}$ & 17 & 101 & $\begin{array}{l}\text { Intraperso } \\
\text { nal }\end{array}$ \\
\hline 7 & Fajar S & $\begin{array}{c}20-08- \\
1999\end{array}$ & 24 & 109 & $\begin{array}{l}\text { Verbal } \\
\text { Linguistik }\end{array}$ \\
\hline 8 & Iqbal & $\begin{array}{c}16-12- \\
1998\end{array}$ & 13 & 89 & $\begin{array}{l}\text { Lerbal } \\
\text { Linguistik } \\
\text { tematika }\end{array}$ \\
\hline 9 & Opik & $\begin{array}{c}05-06- \\
1999\end{array}$ & 21 & 98 & $\begin{array}{l}\text { Interper- } \\
\text { sonal }\end{array}$ \\
\hline 10 & $\begin{array}{l}\text { David } \\
\text { R }\end{array}$ & $\begin{array}{c}09-09- \\
1999\end{array}$ & 11 & 97 & $\begin{array}{l}\text { LogikaMa } \\
\text { tematika }\end{array}$ \\
\hline
\end{tabular}

\subsubsection{Pengguna (User) Normal}

Berdasarkan penyebaran kuesioner penggunaan aplikasi kepada pengguna (user) yaitu anak normal tingkat SMA/SMK yang ada di wilayah Kabupaten Kuningan diperoleh data sebagai berikut :

Tabel 4.9 Data Pengguna (User) Normal

\begin{tabular}{|c|l|c|c|c|l|}
\hline No & Nama & $\begin{array}{c}\text { Tgl. } \\
\text { Lahir }\end{array}$ & $\begin{array}{c}\text { Jwbn } \\
\text { Benar }\end{array}$ & $\boldsymbol{I Q}$ & $\begin{array}{l}\text { Tipe Ke- } \\
\text { cerdasan }\end{array}$ \\
\hline 1 & $\begin{array}{l}\text { Yoyon } \\
\text { S }\end{array}$ & $\begin{array}{c}26-01- \\
2000\end{array}$ & 42 & 114 & $\begin{array}{l}\text { Interper- } \\
\text { sonal }\end{array}$ \\
\hline 2 & Rizki F & $\begin{array}{c}17-07- \\
1999\end{array}$ & 24 & 109 & $\begin{array}{l}\text { LogikaM } \\
\text { atematika }\end{array}$ \\
\hline 3 & $\begin{array}{l}\text { Agus } \\
\text { M }\end{array}$ & $\begin{array}{c}19-12- \\
1999\end{array}$ & 21 & 98 & $\begin{array}{l}\text { LogikaM } \\
\text { atematika }\end{array}$ \\
\hline 4 & $\begin{array}{l}\text { Anissa } \\
\text { I. P }\end{array}$ & $\begin{array}{c}30-10- \\
1999\end{array}$ & 39 & 118 & $\begin{array}{l}\text { Interpers } \\
\text { onal }\end{array}$ \\
\hline 5 & Roni H & $\begin{array}{c}08-11- \\
1998\end{array}$ & 26 & 100 & $\begin{array}{l}\text { Verbal } \\
\text { Linguistik }\end{array}$ \\
\hline 6 & $\begin{array}{l}\text { Indah } \\
\text { L }\end{array}$ & $\begin{array}{c}04-01- \\
2000\end{array}$ & 36 & 105 & $\begin{array}{l}\text { Verbal } \\
\text { Linguistik }\end{array}$ \\
\hline
\end{tabular}

\begin{tabular}{|c|l|c|c|c|l|}
\hline No & Nama & $\begin{array}{c}\text { Tgl. } \\
\text { Lahir }\end{array}$ & $\begin{array}{l}\text { Jwbn } \\
\text { Benar }\end{array}$ & $\boldsymbol{I} \boldsymbol{Q}$ & $\begin{array}{l}\text { Tipe Ke- } \\
\text { cerdasan }\end{array}$ \\
\hline 7 & $\begin{array}{l}\text { Agung } \\
\text { M }\end{array}$ & $\begin{array}{c}28-07- \\
1998\end{array}$ & 33 & 107 & $\begin{array}{l}\text { Interpers } \\
\text { onal }\end{array}$ \\
\hline 8 & Eka R & $\begin{array}{c}06-03- \\
1999\end{array}$ & 48 & 111 & $\begin{array}{l}\text { Interpers } \\
\text { onal }\end{array}$ \\
\hline 9 & Dani S & $\begin{array}{c}22-08- \\
1999\end{array}$ & 21 & 108 & $\begin{array}{l}\text { Verbal } \\
\text { Linguistik }\end{array}$ \\
\hline 10 & Mira P & $\begin{array}{c}14-02- \\
1999\end{array}$ & 30 & 109 & $\begin{array}{l}\text { Interpers } \\
\text { onal }\end{array}$ \\
\hline
\end{tabular}

\section{PENUTUP}

\subsection{Kesimpulan}

Berdasarkan penelitian yang telah dilakukan, dengan dirancang dan dibangunnya aplikasi tes kemampuan $I Q$ dan tipe kecerdasan menggunakan metode binet simon dan metode fuzzy logic untuk anak tunarungu berbasis android, maka dapat disimpulkan bahwa :

1. Tes kemampuan $I Q$ dan tipe kecerdasan anak tunarungu pada SLB C YPALB Perwari Ancaran Kuningan dapat dilakukan dengan cepat, tepat, dan menarik perhatian anak sehingga tes kemampuan $I Q$ dan tipe kecerdasan dapat dilakukan lebih efektif.

2. Dengan mengimplementasikan metode Binet Simon dalam menentukan $I Q$ dan metode Fuzzy Logic dalam menentukan tipe kecerdasan dapat membantu mempermudah dalam proses perhitungan nilai $I Q$ dan tipe kecerdasan dengan cepat dan tepat berdasarkan soal-soal tes yang telah diberikan kepada pengguna (user) yaitu anak tunarungu.

3. Dapat membantu pihak sekolah yaitu SLB C YPALB Perwari Ancaran Kuningan dalam upaya mengembangkan kemampuan kognitif dan emosional, serta 
meningkatkan kemampuan intelegensi siswanya terutama anak tunarungu.

\subsection{Saran}

Setelah merancang dan membangun aplikasi tes kemampuan $I Q$ dan tipe kecerdasan menggunakan metode binet simon dan metode fuzzy logic untuk anak tunarungu berbasis android, peneliti memiliki beberapa saran sebagai pengembangan di masa mendatang, yaitu sebagai berikut :

1. Aplikasi tes kemampuan $I Q$ dan tipe kecerdasan ini dapat digunakan oleh sekolah-sekolah lainnya terutama Sekolah Luas Biasa (SLB) ataupun oleh masyarakat umum yang memiliki kelebihan yaitu tunarungu untuk mengetahui $I Q$ dan tipe kecerdasan yang dimilikinya.

2. Aplikasi tes kemampuan $I Q$ dan tipe kecerdasan diharapkan dapat melakukan pengelolaan soal-soal tes $I Q$ dan tipe kecerdasan oleh pihak sekolah, sehingga aplikasi ini dapat digunakan bukan hanya untuk anak tunarungu saja tetapi untuk anak yang memiliki kelebihan-kelebihan yang berbeda

3. Aplikasi tes kemampuan $I Q$ dan tipe kecerdasan ini dapat dipadukan atau dilengkapi dengan tes kepribadian ataupun tes yang lainnya.

\section{DAFTAR PUSTAKA}

[1] Ahmadi, Abu. 2009. Psikologi Umum. Jakarta: Rineka Cipta.

[2] Fudyartanta, Ki. 2004. Tes Bakat dan Perskalaan Kecerdasan. Jakarta: Pustaka Pelajar.
[3] Gardner, Howard. 2003. Kecerdasan Majemuk: Teori dalam Praktek. Alih Bahasa: Arvin Saputra. Batam: Interaksara.

[4] Jogiyanto, Hartono M. 2005. Analisa dan Desain Sistem Informasi: Pendekatan Terstruktur Teori dan Praktik Aplikasi Bisnis. Yogyakarta: ANDI.

[5] Ladjamuddin, Al-Bahra. 2006. Pengujian Perangkat Lunak. Yogyakarta: ANDI.

[6] Pressman, Roger S. 2002. Rekayasa Perangkat Lunak: Pendekatan Praktisi. Yogyakarta: ANDI.

[7] Rosa A.S dan M. Shalahuddin. 2013. Rekayasa Perangkat Lunak: Terstruktur dan Berorientasi Objek. Bandung: Informatika.

[8] Sri, Kusumadewi. 2013. Aplikasi Logika Fuzzy untuk Pendukung Keputusan Edisi II. Yogyakarta : Graha Ilmu.

[9] Sukardi, D. K. dan Kusmawati, D. P. E. N. 2009. Analisis Tes Psikologi Teori dan Praktik dalam Penyelenggaraan Layanan Bimbingan dan Konseling di Sekolah. Jakarta: Rineka Cipta.

[10] Sumantri, Sutjihati. 2006. Psikologi Anak Luar Biasa. Bandung PT. Rafika Aditama.

[11]Tes Kemampuan Differensial (TKD). Jakarta: Lembaga Pengembangan Sarana Pengukuran dan Pendidikan Psikologi (LPSP3) Fakultas Psikologi-Universitas Indonesia. 